\title{
Reconceptualization of National Spaces: A Close Reading of Bharati Mukherjee's selected novels with Gloria Anzaldúa's Nueva Conciencia Mestiza
}

\author{
Shilpi Gupta
}

University of Granada, Spain, shilpigupta.jnu@gmail.com, shilpigupta@correo.ugr.es

https://orcid.org/0000-0002-6786-6656

\begin{abstract}
In 1997, Bharati Mukherjee, a renowned diaspora woman writer, stated in an interview, "I am an American, not an Asian American." Since then, she has been virulently attacked for defining herself as an American by the writers of her original homeland and her diaspora compatriots. However, with this statement, Mukherjee challenged the diaspora writing and took a solid move to redefine the diaspora through her life and novels. Her novels also considered her autobiographical notes, demonstrate a new diaspora identity that is fluid and transforming. Her latest diaspora writing has challenged the quintessential diaspora identity, gender structure, definition of home, and host land. The paper will do a close reading of her four novels, The Tiger's Daughters (1971), wife (1975), Jasmine (1989), and Desirable Daughters (2002), to see the transition from being a Bengali Indian expatriate in Canada, Asian American to American Immigrant. In the paper, her four novels are divided into two phases- expatriate and immigrant, which show different writing styles, different psychology behind the narration, and transition in her definition of the nation. This discussion will employ the theory of Nueva Conciencia Mestiza given by Gloria Anzaldúa to comprehend the reconceptualization of national spaces from the perspective of diaspora women.
\end{abstract}

Keywords: Bharati Mukherjee, Diaspora woman, Nation, Nueva Conciencia Mestiza

\section{Bharati Mukherjee}

Having migrated to the US for the first time in 1962, Bharati Mukherjee was born in Calcutta in 1940 into a prominent Bengali family, an affluent neighborhood. Her father, Dr. Sudhir Lal Mukherjee, was a well-known pharmaceutical chemist and her mother, Bina Banerjee Mukherjee, was a homemaker. Bharati Mukherjee spent her first eight years as a member of a large extended family. Shortly after India gained independence, she lived with her parents and two sisters in London for about three years, where she became fluent in English. In 1951 the family returned to Calcutta, and Bharati Mukherjee joined the Englishspeaking Loreto Convent School, run by Irish nuns. Quite characteristic of this class of Bengalis, the family was "westernized" in the sense that English education was valued, and much literature, philosophy, and social principles were transmitted through the language. However, in more intimate convictions, the family observed high caste Hindu practices and beliefs. 
She lived with her parents in comfortable circumstances since her father was a pharmaceutical factory co-owner. She took her bachelor's degree from Calcutta University. In 1962 she was chauffeured to the US to study Creative Writing. In American Dreamer, Mukherjee reveals the moment of flying to the USA:

I flew into a small airport surrounded by cornfields and pastures, ready to carry out the two commands my father had written out for me the night before I left Calcutta: Spend two years studying Creative Writing at the Iowa Writer's Workshop, then come back home and marry the bridegroom he selected for me from our caste and class. $(1997,1)$

However, America changed her. Once there, she determined to stay on and in 1963 married a Canadian writer, Clark Blaise. She married someone who was neither of her caste, religion, or country. This decision set her against her father, and she admitted that "that act cut me off forever from the rules and ways of upper-middle-class life in Bengal and hurled me into a New World life of scary improvisations and heady explorations (Mukherjee, 1997, 2). She decided not to settle in India - "it would have been more challenging for me to have lived in Calcutta with a white American professor than for me, an Indian wife, to live in a multicultural society here" (Mukherjee in Vignisson, 1992-3, 159).

\section{"I am an American, not an Asian American": Bharati Mukherjee}

In American Dreamer, Indian-born American writer Bharati Mukherjee eloquently declares, "I am an American, not an Asian American" (1997). On this note, she has been criticized by many intellectuals. For instance, Malashri Lal points out that Mukherjee has become "a propagandist on behalf of a new community and tends to downgrade her Indian heritage and affiliations" (Lal, 1995, 149). Similarly, Ragini Ramachandra criticizes her as "the one, who has become a source of considerable embarrassment in recent times to a sensitive, discerning, [and] self-respecting Indian reader (Ramachandra, 1991, 56). Ramachandra further criticizes Mukherjee's pride in "growing less and less Indian" with every passing year and blatantly making a virtue of her rootlessness $(1991,56)$.

Mukherjee's statement "I am an American" was uttered in 1997 after she had lived as an expatriate in Canada and traveled back to India with her husband. Her decision to be called an American was not an immediate reaction after leaving India; it was a process that took decades to say. While crossing the physical borders, she crossed the metaphorical borders which reshaped her identity as a diaspora, a woman, a Third World migrant. Hence taking the case study of a diaspora woman writer and her female diaspora characters, the paper will delve into some questions- Does the home/land accept the diaspora woman who goes not only outside her country but outside her religion and caste? Does a diaspora woman wish to go back to her home/land? Why is a diaspora woman burdened with the choices to make between homeland and host land or between homes (father's and husband's)? Despite changing the land, how is diaspora woman trapped in the patriarchal norms of homeland?

Also, the chapter will focus on the two different phases of her life where she calls herself an expatriate and then an immigrant. Hence some other questions are- What is the difference between expatriate and migrant from the writer's point of view? How an immigrant (who is 
supposed to be free from his/her past) negotiates with the past? Does an immigrant challenge the expatriate? How is diaspora woman challenging the definition of home/land based on the modern construction of nation? How does a diaspora woman define her home/land?

In this paper, close reading is used as a methodology to enter the texts of Bharati Mukherjee, where I will be departing from the theory of postcolonial feminism and transnational feminism, which see the complexity of any subject beyond gender. In this regard, the paper will debate the theory of Nueva Conciencia Mestiza to understand the reconceptualization of national spaces from the perspective of diaspora Third world women.

\section{The Writer and Her Writings}

As a writer, Mukherjee has written several novels, some of them are best sellers. The Tiger's Daughter(1971), Wife (1975), Jasmine (1989), The Holder of the World(1993), Leave it to Me (1997), Desirable Daughters (2002), The Tree Bride (2004), and two anthologies of short stories, Darkness (1985) and The Middleman and Other Stories (1988). Her writings capture vividly the process of migration, the migrant life of characters, the feeling of alienation as expatriates and the Indian woman sojourning abroad, and her struggle for identity. Mukherjee's works also present the autobiographical elements where Mukherjee, through her character, portrays her struggle to negotiate the traps and opportunities of old and new, and past and present, first as an exile from India, then as an Indian expatriate in Canada, and finally as an immigrant in the USA. Her works correspond with the various phases of her life, as her protagonists are close projections of herself. "I thought I was writing about people who were totally outside of me. I realize now that the novels are sort of way station in my Americanization" (Desai, Interview 1998). In this way, Mukherjee intends to represent herself through the characters of her novels. Of course, she puts her characters in different scenarios in diaspora lives, but she shows her mental conflicts through her protagonists.

Her writing embodies her sense of what it means to be a woman writer of Bengali Indian origin who crossed the border(s) from India to the USA. A writerr lived in India, Canada, and America, who lived 16 years within a high-caste, upper-middle-class extended family structure, married outside her caste, class, nationality, and religion. In her book Feminism and the PostModern Women Novelists in English, Anita Myles quoted the words of Mukherjee given in an interview: Fiction must be a metaphor. It is not a transcription of real-life but a distillation and pitching at the higher intensification of life. It is always a distortion (160).

Through her writings from The Tiger's Daughter (1971) to Desirable Daughters (2002), one can sense the conflict she was going through. There has been an ongoing quest from expatriation to immigration in her writing. These are two different diaspora identities. Mukherjee's distinction between expatriation and immigration displays what Edouard Glissant, in the Caribbean context, explains. Expatriation, according to him, is an "obsession with a single origin" who does not wish to change what he or she perceives to be the "absolute" state of being. He or she reverts to avoid cultural contact and interaction. 
On the other hand, the immigrant is willing to be changed into something new, into a new set of possibilities" (Glissant, 1989, 14-16). In this research writing, that shift from expatriate to immigrant can be viewed in her novels. These four novels debate the diasporic themes from the perspective of the Third World diaspora women who carry the baggage of their class, caste, religion, nationality, colonial background, and their feminine duty as a mother, widow, wife. It is vital to comprehend that the writer does not write only as a diaspora, expatriate, or immigrant. In each novel, her South Asian diaspora women are portrayed as married to a foreigner, unhappy wife, widow, and divorcee single mother.

As they are first-generation migrant women from different levels of society, they may show a typical notion of an in-between position that contrasts West-East and First-Third Worlds. These novels will show a shift from the rejection of in-betweenness to celebrating the new in-between identity. Being first-generation migrant women determines the process of self-adaptation in and to the host land because -longing for homes left behind may be intense for first-generation immigrants who see a community to belong to.

\section{Expatriate: A shadow of past in The Tiger's Daughter and Wife}

Examining Mukherjee's works reveals a movement from expatriation to immigration and a change in her internal conflict. This movement coincides with her immigration from Canada to the USA. Mukherjee's interpretation of her experience in Canada led her to see herself as an expatriate. The novels which she has written during that period reflect the themes of expatriation. In the first two novels, The Tiger's Daughter(1971) and Wife (1975) - where one can see the attempt to search for Indianness, her past, trying to become an Indian, struggling between be/longingness, between dis/loyal, going through internal conflict, trying to fulfill the roles which she carried along, searching her home, searching to settle, being rejected by her homeland and not able to accept the new one. Confusion, fear, and being lost are some of the characteristics of the protagonists of her novels.

Starting from The Tiger's Daughter, written in 1971, the protagonist Tara makes an ambitious journey back to India after many years to discover her home infested with a denuded tradition of poverty, squalor, and turbulence. India, especially Calcutta, was not the way she imagined. Tara wanted to visit Calcutta she left behind but felt deceived. Either she failed her home, or her home failed her. Tara lucidly shows how the return of a diaspora to her homeland is not easy. Avtar Brah, in this context, writes that:

Homeland, as the origin is an important term, is only a myth where it is not possible to return because it does not exist anymore. The left homeland was a different place years ago or months ago, and it does not remain the same. It could be possible to visit the geographical territory that looks like the origin. (Brah, 1996, 192)

It is even more difficult for an Indian diaspora woman who marries outside the country because she has crossed not only the physical borders but also the borders of caste and religion. Her homeland does not see her as a woman of its caste, religion rather as an Americawali and less Indian. 
Because of being treated as an outsider, she struggles between Indianness and Americanness, between Tiger's daughter and Americawali. She is trying to prove that she is more Indian than American, but she is not content with the tags. "In India, she felt she was not married to a person but to a foreigner and this foreignness was a burden. It was hard for her to talk about marriage responsibilities in Carmac Street" (Mukherjee, 1975, 62). David is vociferous in his letters about his feelings. His concern about Tara is also palpable. On the other hand, Tara is evasive in her replies and contrives to hide her true sentiments, "So Tara confided secrets in her letters to her husband but managed quite deftly not to give her feelings away" (130). The last sentence of the novel itself embodies her being closed and confused.

And Tara, still locked in a car across the street from Catelli-Continental, wondered whether she would ever get out of Calcutta and, if she didn't, whether David would ever know that she loved him fiercely. (248)

Wife (1975) blends the writer's attitudes towards India, Canada, and the USA. In the novel, Dimple, the protagonist, moves from Calcutta to the USA, though the writer was in Canada while writing the novel. The novel partly reflects Mukherjee's difficulties adapting to life in Canada, where she was racially other. The protagonist displays the similar frustration that the writer went through while living in Canada. Dimple is not able to settle; she feels lost, trying to find her home, but is always deceived by Brahmanical patriarchal structure and racial discrimination. From the beginning, she looks for her home and her freedom in it, which she thinks she will first find at her husband's home. Unfortunately, she fails and thinks the other country will free her, but the Brahmanical patriarchal system does not let her off. She gets chances to live different lives, but she is reminded about the wife's role either by her husband or by "the other" herself, who is feared of patriarchy.

Even Dimple wants to live and accept the host land, either her husband (who symbolizes the homeland) or discrimination outside at host-land is not letting her flow. The wifely duty and the loyalty of Dimple reflect the loyalty which Mukherjee carries with her, in both cases it is imposed. Dimple's effort to retain her Indianness shows that she does not wish to give away her past, her "original" identity. The past becomes a burden in her subjectivity. Fakrul Alam writes that "Mukherjee here focuses on an Indian wife who is willing to immerse herself in the life and the mores of urban America but who is also being pulled back at least for the time being, by her Indianness" $(1996,83)$. She resists inclusion in the new host society, which symbolizes Mukherjee's situation as an expatriate.

\section{Immigrant: Re-incarnation in Jasmine and The Desirable Daughters}

The journey from Wife to Jasmine is a severe psychological change in the protagonist, the writer, and readers. In this phase of writing, the writer is expecting her readers to undergo unlearning and learning. It looks that Tara and Dimple of her earlier two novels have freed themselves from the social norms and reincarnated as Jyoti. Also, the murder of Amit, Dimple's husband, symbolizes her take on liberating herself from the Brahmanical patriarchal norms and leaving those suppressing cultures behind. As far as the writer is concerned, 1984 is a turning 
point in her sensibility and style when she shifted to the USA. She reveals that she is freed of the debility of expatriate nostalgia by the stringencies of life in the New World. In the second half of her career, she wrote Jasmine (1989) and Desirable Daughters (2002). In the later part of her writings, her "immigrant" is prepared to discard nostalgia.

Jasmine is a novel of re-incarnation where Mukherjee affirms, "I have been murdered and reborn at least three times; the correct young woman I was trained to be and was very happy be, is very different from the politicized, shrill, civil rights activist I was in Canada, and from the urgent writer that I have become in the last few years in the United States. I cannot stop" (Interview, 1990,18). Similarly, in Jasmine, we see the evolution of the central character as she enters the unfamiliar American culture and goes through an oscillating series of painful and joyful experiences. The character goes through the cyclical narrative pattern of destruction and renewal where she experiences a series of deaths and rebirths as her identity evolves in her passage from life as Jyoti, the Punjabi villager, to Jasmine and Jane. Jasmine carries her past but is ready to flow with the present because she does not have many options. It is not easy for Dimple to get rid of the past. She keeps on oscillating about her painful past and moves on with it.

The next novel, Desirable Daughters, is written in 2002 when the writer had already called herself American in 1997. In the novel, it is interesting to see the picturization of three sisters from the same family, the same culture, the same school, the same upbringing, and even having the exact birthdate, but they take different paths in their life. With this background, the writer accepts differences among diaspora who may have similar roots, but their routes may differ. Padma, the eldest daughter, and Tara, the protagonist, both lived in the USA, are examples of expatriates and migrants. On the one hand, Padma is not ready to accept cultural changes and is proudly closed within the high-caste, upper-middle-class Indian origin diaspora. She abhors American cultural influences and clings to Indian friends, clothes, and food. Even she abuses Tara for being going out of her marriage and living with a boyfriend. She keeps calling her American. Padma and Parvati, the middle sister, do not need to widen their horizons and are less assertive and stick to the safer side. Tara, on the contrary, challenges the Indian high-caste, an upper-middle-class wifely role which she was taught and that two other sisters were following. She also challenges the border, which divides Indians and Americans. She flows from one side to another quickly and accepts the new identity. For such a change in her identity, she is criticized for becoming American and losing Indianness.

In her earlier novel, Jasmine suggests that migration to America means a new opening and freeing the self from the conventional bound society and past, whereas, in Desirable Daughters, she considers various patterns of belonging in the global perspective. The ties with a homeland and the past are presented as essential in creating the interstitial place in the host country. The past in the novel plays an essential role in constructing the present. To understand herself and recreate a new identity for her, she must delve into the past and unfold its intricacies. She begins to narrate the story of her ancestral namesake, Tara Lata, the Tree Bride of Mishtigunj. The story moves with ease from past to present, from India to America and from Calcutta to California, that it seems that the boundaries between these two different geographical worlds do not exist. From Jasmine to the Desirable Daughter, there has been a psychological shift in the writer. Jasmine, on the one hand, moves ahead, leaving the past behind. Tara, on the other, balances the past and present. 
In four of her novels, Bharati Mukherjee and her female protagonists have shifted from an expatriate to an immigrant. Through these novels, she is trying to redefine the meaning of homeland for her female characters and herself. Intriguingly, the shift from expatriate to immigrant, from past to present, from original homeland to a new land, is not easy. It has its challenges; the shift will be read through the theory of Nueva Conciecia Mestiza.

\section{Reconceptualization of national spaces}

The shift between be/longingness, between dis/loyalty, between home and host land questions the roots and routes of the protagonists. Paul Gilroy suggests that it is significant to understand the tension between "roots" and "routes" in the study of identity "the routes keep disestablishing the identity and re-creating it at every instant" (Gilroy, 1993, 133).

From the perspective of the diaspora who carry their gender, color, and Third World identity, the definition's roots and routes are complex and unique. Theoretically, these terms emphasize the modern construction of a nation. Benedict Anderson talks about the nation as an imagined community and nationalism as its fruit which traveled from imperialist countries to their colonial states. He further says that the "motherland" or "home" (the colonial motherland) becomes a domain of "dis/interested love and solidarity," which demands loyalty, patriotic inclination, and profound self-sacrificing love (Anderson, 1983, 144). Indeed, the transnational movement and diaspora formation is the counter-narrative of the border of nation and state. However, the postcolonial and transnational critics see the idea of nationalism, nationhood, and nation-ness as colonialism's greatest gift of modernity to the colonies and as a long-lived ideological mainstay. Tölölyan says that "infranational and transnational alternatives to the nation-state has led to a realignment of collective emotional investment, nationalism and other forms of loyalty which will compete for a long time" (Tölölyan, 1991, 7).

From a transnational feminist perspective, Susan Strehle suggests that home and homeland are based on "imperialist philosophies of nation construct." Home/land defines "settling down" (which could be unsatisfactory), "marriage," stability, separation from the outer, and a patriarchal space. It emerges in the valorization of accomplished "housewifery," which involves managing resources, not your own. (Strehle, 1998, 3-12) Strehle's definition of homeland compared with home and nation gives the proper idea of the homeland, which is referred to in the paper.

\section{Situating Mukherjee and her protagonists: Nueva Conciencia Mestiza}

At this point, I would like to introduce the notion of Nueva Conciencia Mestiza. Gloria Anzaldúa introduced the theory of Nueva Conciencia Mestiza in her path-breaking book Borderlands/ La Frontera: The New Mestiza (1987). Gloria Anzaldúa (1942-2004) belongs to the Chicana population in Texas, which was once Mexican land. The Mexican population became migrants in the nineteenth century when the United States frontier moved towards the South. In Borderlands (1987), she defines the border based on her Chicana identity, her "in-betweenness" in Mexico and 
the USA, and then she also defines the borderlands in metaphorical terms. She exclaims that "a borderland is a vague and undetermined place created by the emotional residue of an unnatural boundary. It is in a constant transition. The prohibited and forbidden are its inhabitants" (Anzaldúa, 1987, 3).

Although Anzaldúa comes from different historical and cultural baggage and has different experiences of crossing geographical borders, she comes together with Mukherjee to define the borderlands from a marginal perspective. It is significant to highlight the lingual, gender, and racial difference of the writers. Mukherjee's familial and economic background has given her the advantage of being an expert of English and other vernacular languages, whereas Anzaldúa writes in Chicana language, which is considered a "bastard language." Mukherjee is a heterosexual, married to a North American writer, whereas Anzaldúa chooses to be a queer. As a Third World woman, Mukherjee is racially discriminated whereas Anzaldúa carries her mestiza identity, taboo as a traitor's body. However, the writers go through the in-betweenness, dual conflicts and describe the mental conflict and the situation of ambivalence from the perspective of women. This paper will focus on the psychological perspective, which Anzaldúa explicitly discusses through Nueva Conciencia Mestiza and Coatlicue State.

The proposed theory helps to understand the psychological shift of Mukherjee and her protagonists from the position of an expatriate to an immigrant. In this regard, I will investigate the "Coatlicue State," which illustrates the "mental state" of subjects, and then enter the discussion of "Nueva Conciencia Mestiza" through the "Coatlicue State."

In the first two novels, The Tiger's Daughter and Wife, it is seen that the protagonists are struggling between identities, not able to accept themselves, stuck between loyalty and disloyalty. They are confused, alone, and fearful. Anzaldúa explains this situation through Coatlicue State "the ambivalence from the clash of voices results in mental and emotional states of perplexity, Internal strife results in insecurity and indecisiveness. The mestiza's dual or multiple personalities is plagued by psychic restlessness" (Anzaldúa, 1987, 78). A state of in-betweenness, where one goes deeper into the darkness where one can lose oneself or find oneself. Anzaldúa, to delineate such situation describes the Coatlicue State as:

An Aztec goddess of death and birth. She has a human skull and serpent for a head, a necklace of human hearts, a skirt of twisted serpents, and taloned feet. She is the creator of the celestial body. She contained and balanced the dualities of male and female, light and dark, life and death. Simultaneously, depending on the person, she represents duality in life, a synthesis of duality, and a third perspective-something more than mere duality or synthesis of duality (Anzaldúa, 1987, 46).

Anzaldúa uses Coatlicue to talk about the struggle to get out from the position of the "other," -marginalized other. This state is critical because it stresses accepting one being a minority, a woman, a racially other, and the "other." Rosi Braidotti expresses that those who are already "other" may first need to go through a phase of "identity politics," that is, claiming a fixed location before getting into the struggle against its construction (Braidotti, 2000, 36). Anzaldúa also claims that this "Coatlicue State" process seems to be a painful mental and emotional state of perplexity as to the site of conflict between inner and outer voices. 
Then Anzaldúa explicitly writes that standing on the opposite river bank is not enough, shouting and challenging patriarchal, white convention. At some point, on our way to a new consciousness, we will have to leave the opposite bank and cross the border into the wholly new and separate territory. We might go another route. The route to divergent thinking, characterized by movement away from set patterns and goals and toward a more whole perspective, one that includes rather than excludes(78).

Hence, Nueva Conciencia Mestiza explains beyond the internal conflict in preparation of a conscious other. It constructs a new identity, a new and conscious self. It is the space of achieving consciousness, a new mestiza consciousness, a consciousness of being other, a consciousness of borderlands, una conciencia de mujer (Anzaldúa, 1987, 77). She points out that this inbetweenness is not an assembly where separated pieces merely some together, nor about balancing "us" and "them." Instead than work out a synthesis, the self has added a third element more significant than the sum of its severed parts. It is the "Nueva Conciencia Mestiza" that develops at the borderlands- an in-between space and among those who are "prohibited" and "forbidden."

If we see Mukherjee's novels, there is a tremendous mental shift in the character from the first novel, The Tiger's Daughter, to Desirable daughters. Similar psychological change has been interpreted in the writer who moved from her first writing to Jasmine (1989) and Desirable Daughter (2002). At the end of the ' $80 \mathrm{~s}$, she wrote Jasmine, calling herself genetic and not hyphenated $(1989,222)$.

In the last two novels, in place of dividing her loyalty, she chose an adaptive response towards achieving the conscious self. Mukherjee chose to be called an American and not Asian American, an immigrant and not expatriate, moving forward and not suffering from the past. She is conscious that measuring oneself through the eyes is not psychologically healthy, which she is doing primarily in her first two novels. In her third novel, Mukherjee becomes more adaptive and prefers to move ahead without letting others tag her. She chose to change her path in her writing style and to be genetic than hyphenated. In 2002, with the publication of Desirable Daughters, she showed her new self. She chose to find a balance between her memories and the present. Hence, she preferred to be psychologically healthy amidst all the critics. Besides, Mukherjee's immigrant aesthetics in claiming an American national cultural identity and opposing a hyphenated (Asian American) in a political and ideological movement refuses to categorize national space as dominant/ minority and center/periphery. Becoming American is her shift from expatriate to immigrant. It is a challenge to the South Asian diaspora writers (male) and the American mainstream. Accepting being American is accepting being called a traitor by her compatriots. Also, it is accepting being an outsider, non-European, Third world woman within the American mainstream. Mukherjee prefers to be called an outsider within American society, a Third World woman in First World, an outcast in Indian society. Anzaldúa says the new mestiza copes by developing a tolerance for contradictions and ambiguity(78).

\section{Conclusion}


Mukherjee's characters of the first two novels, Tara and Dimple, have struggled to find their identity between home and host land, between India and America, between past and present, between loyalty and disloyalty, in search of their identity, their home. Hence the novel's endings display that the writer and her characters are not satisfied within the home divided and broken and burdened with gender, caste, and nation. In the other last two novels, Jyoti and Tara are moving towards a position of "conscious other" from the position of the "other," which is the binary position of the "self." These conscious characters are on the road to achieve their mental peace first and then struggle in the outside world. Mukherjee says that my task as an author is to make my intricate, unknown world comprehensible to mainstream Americans. Certainly, her characters are not losing themselves in the mainstream but expanding the margins of what one may call American experiences. For Instance, Jyoti is a new immigrant who is not afraid of what she is, she is far from the nostalgia of the past, not afraid of the unfamiliar present. Tara of Desirable Daughter knows how to balance the past with her present and become confident being at in-between.

Hence through her characters, she resists the workings of the binary and marginalizing strategies of the dominant cultural discourse; Mukherjee conceptualizes the assimilation as something genetic rather than hyphenated, with the power to challenge the static borders of national and cultural identity. Mukherjee's immigrant poetics endeavors to dismantle the binary opposition of the "us" and "them" paradigm to construct the nation as a new area of negotiation of meaning and representation, the site of re-forming.

\section{Work cited}

Adams, Bella. (2008). Asian American Literature. Edinburgh University Press.

Anderson, Benedict. (1983). Imagined Communities: Reflections on the Origin and Spread of Nationalism. London: Verso.

Anzaldúa, Gloria Evangelina. (1987). Borderlands/La Frontera: The New Mestiza. San Fransisco: Aunt Lute

Braidotti, Rosi. (2003). Becoming woman: or sexual difference revisited. Theory, Culture \& Society, Vol. 20(3), (pp. 43-64). London: Sage.

Glissant, Edouard. (1989). Caribbean Discourse: Selected Essays. trans. J. Michael Dash, Charlottesville: University of Virginia Press.

Mukherjee, Bharati, Blaise, C., Connell, M., Grearson, J., \& Grimes, T. (1990). An Interview with Bharati Mukherjee. The Iowa Review, 7-32.

Mukherjee, Bharati. (1997). American dreamer. Mother Jones, 22(1), 32-35.

Mukherjee, Bharati. (1991) A Four-Hundred-Year-Old Woman. The Writer on Her Work: New Essays in New Territory. Ed. Janet Sternbury. Vol. 2. New York and London: W.W. Norton. pp. 33-8.

Mukherjee, Bharati, Tina Chen, and S.X. Goudie. 1997. Holders of the Word: An Interview with Bharati Mukherjee, Holders of the Word: An Interviewwith Bharati Mukherjee (archive.org)

Myles, Anita. 2006. Feminism and the Post-Modern Indian Women Novelists in English. Sarup\& Sons. 
11 Reconceptualization of National Spaces: A Close Reading of Bharati Mukherjee's selected novels with Gloria Anzaldúa's Nueva Conciencia Mestiza

Nayar, Pramod. (2010) Postcolonialism: A Guide for the Perplexed. London: Continuum.

Nelson, E. S. (2017). Bharati Mukherjee: Critical Perspectives (Vol. 1). Routledge.

Palumbo-Liu, David (1995). The ethnic canon: Histories, institutions, and interventions. U of Minnesota Press.

Ramachandra, R. (1991). Bharati Mukherjee's Wife: An Assessment. The literary criterion, 26(3).

Shah, M. F. Bharati Mukherjee's Craftsmanship in Desirable Daughter.

Singh, Amritjit and Schmidt, Peter (2000). South Asian American Literature: 'Off the Turnpike' of Asian America. Postcolonial Theory and the United States: Race, Ethnicity and Literature. Mississippi: University Press of Mississippi. 372.

Shefali Desai, Tony Barnstone, \& Mukherjee, B. (1998). A Usable Past: An Interview with Bharati Mukherjee. Manoa, 10(2), 130-147. Retrieved January 20, 2021, from http://www.jstor.org/stable/4229687

Strehle, Susan. (2008). Transnational women's fiction: Unsettling home and homeland. New York: Palgrave Macmillan.

Tölölyan, Khachig. (1991). The Nation-State and Its Others: In Lieu of a Preface. Diaspora: A Journal of Transnational Studies, Vol. 1(1), (pp. 3-7). Accessed October 13, 2017. http://dx.doi.org/10.1353/dsp.1991.0008

Vignisson, R. (1992). Bharati Mukherjee: An Interview. SPAN: Journal of the South Pacific Association for Commonwealth Literature and Language Studies (SPAN), Vol34-35, 4.

Wong, Sau-Ling Cynthia (1993). Reading Asian American literature: From necessity to extravagance. Princeton University Press. 